\title{
Ecosystem for the deployment and management of virtual laboratories based on the standard IMS LTI
}

\author{
Frey Alfonso Santamaría-Buitrago ${ }^{1}$ \\ Javier Antonio Ballesteros-Ricaurte ${ }^{2}$ \\ Ángela María González-Amarillo ${ }^{3}$
}

Fecha de recepción: 11 de mayo de 2019

Fecha de aprobación: 25 de septiembre de 2019

\begin{abstract}
The advancement of information and communication technologies occurs due to the evolutionary capacity of computer equipment as well as the existence of increasingly sophisticated tools and applications. Virtual laboratories, a flexible tool which allows to design, simulate, model and test through experimentation real-life processes, are an example. Virtual laboratories have a great impact on engineering as they improve accessibility to experiments, facilitating the development of strategies in the field of education; they include interactive ways to observe, illustrate, demonstrate and investigate, aside from support system users in the elaboration and exchange of results. For this reason, the experience reflected in this article highlights the design and implementation of an ecosystem for the deployment and management of virtual laboratories, based on the IMS Learning Tools Interoperability standard. In this process, the methods and technologies applicable to the development of virtual laboratories are characterized with an instructional model for experimental environments that identifies the scope of the procedure and the technical criteria, taking into account LabManager, WebLabDeusto and LMS Sakai, and finally the installation and configuration of the cloud platform and the laboratory prototype that responds to the proposed ecosystem.
\end{abstract}

Keywords: cloud computing; digital ecosystem; virtual lab.

\footnotetext{
1 M.Sc. Universidad Pedagógica y Tecnológica de Colombia (Tunja-Boyacá, Colombia). frey.santamaria@uptc.edu.co. ORCID: 0000-0002-5339-6518.

2 Ph.D. (c). Universidad Pedagógica y Tecnológica de Colombia (Tunja-Boyacá, Colombia). javier.ballesteros@uptc.edu.co. ORCID: 0000-0001-9164-4597.

${ }^{3}$ MBA. Universidad Nacional Abierta y a Distancia (Tunja-Boyacá, Colombia). angela.gonzalez@unad.edu.co. ORCID: 0000-0002-3568-7530.
}

Revista Facultad de Ingeniería (Rev. Fac. Ing.) Vol. 28 (53), pp. 79-99. Octubre-Diciembre 2019.

Tunja-Boyacá, Colombia. L-ISSN: 0121-1129, e-ISSN: 2357-5328, DOI:

https://doi.org/10.19053/01211129.v28.n53.2019.10148 


\section{Ecosistema para el despliegue y manejo de laboratorios virtuales basado en el estándar IMS LTI}

\section{Resumen}

El avance de las tecnologías de la información y la comunicación se debe a la capacidad evolutiva de los equipos informáticos, así como a la existencia de herramientas y aplicaciones cada vez más sofisticadas. Un ejemplo son los laboratorios virtuales, herramienta flexible que permite diseñar, simular, modelar y probar a través de procesos de experimentación de la vida real. Los laboratorios virtuales tienen gran impacto en la ingeniería, ya que mejoran la accesibilidad a los experimentos, facilitando el desarrollo de estrategias en el campo de la educación; incluyen formas interactivas para observar, ilustrar, demostrar e investigar, además de apoyar a los usuarios del sistema en la elaboración y el intercambio de resultados. Por este motivo, la experiencia reflejada en este artículo destaca el diseño y la implementación de un ecosistema para el despliegue y la gestión de laboratorios virtuales, basado en el estándar de interoperabilidad de herramientas de aprendizaje IMS. En este proceso, los métodos y tecnologías aplicables al desarrollo de laboratorios virtuales se caracterizan con un modelo de instrucción para entornos experimentales, que identifica el alcance del procedimiento y los criterios técnicos, teniendo en cuenta LabManager, WebLabDeusto y LMS Sakai, y, finalmente, la instalación y configuración de la plataforma en la nube y el prototipo de laboratorio que responde al ecosistema propuesto.

Palabras clave: computación en la nube; ecosistema digital; laboratorio virtual.

\section{Ecossistema para a implantação e gestão de laboratórios virtuais baseado no estândar IMS LTI}

\section{Resumo}

O avanço das tecnologias da informação e a comunicação deve-se à capacidade evolutiva dos equipamentos informáticos, assim como à existência de ferramentas e aplicações cada vez mais sofisticadas. Um exemplo são os laboratórios virtuais, ferramenta flexível que permite desenhar, simular, modelar e provar através de processos de experimentação da vida real. Os laboratórios virtuais têm grande impacto na engenharia, já que melhoram a acessibilidade aos experimentos, facilitando o desenvolvimento de estratégias no campo da educação; incluem formas interativas para observar, ilustrar, demonstrar e pesquisar, além de apoiar aos usuários do sistema na elaboração e no intercâmbio de resultados. Por este motivo, a experiência refletida neste 
Frey Alfonso Santamaría-Buitrago, Javier Antonio Ballesteros-Ricaurte, Ángela María GonzálezAmarillo

artigo destaca o desenho e a implementação de um ecossistema para a implantação e a gestão de laboratórios virtuais, baseado no estândar de interoperabilidade de ferramentas de aprendizagem IMS. Neste processo, os métodos e tecnologias aplicáveis ao desenvolvimento de laboratórios virtuais caracterizam-se com um modelo de instrução para entornos experimentais, que identifica o alcance do procedimento e os critérios técnicos, considerando LabManager, WebLabDeusto e LMS Sakai, e, finalmente, a instalação e configuração da plataforma na nuvem e o protótipo de laboratório que responde ao ecossistema proposto.

Palavras chave: computação na nuvem; ecossistema digital; laboratório virtual.

\section{Para citar este artículo:}

F. A. Santamaría-Buitrago, J. A. Ballesteros-Ricaurte, and A. M. González-Amarillo, "Ecosystem for the deployment and management of virtual laboratories based on the standard IMS LTI," Revista Facultad de Ingeniería, vol. 28 (53), pp. 79-99, Oct. 2019. https://doi.org/10.19053/01211129.v28.n53.2019.10148.

Esta obra está bajo licencia internacional Creative Commons Reconocimiento 4.0

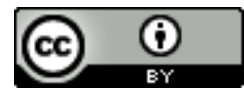




\section{INTRODUCTION}

From biology, "an ecosystem represents a system consisting of a community of living organisms and the physical environment where they are related, they usually form a series of chains that show interdependence of organisms within the system and the complex interactions between the organisms that form the community and the energy flows and materials that cross it" [1].

Similarly, when talking about digital ecosystems, the interdependence and complexity of biological ecosystems is taken as a metaphor [2]. In this case, it is an environment created using the digital environment of cyberspace, which seeks to generate the most favorable scenarios for a project on the internet.

Applications, services, infrastructure and users are the basic elements of a digital ecosystem [3], which in their interdependence must be developed to generate a result from a political, commercial and / or pedagogical intention, among others.

Taking into account the above and aware of the changes in education environments, and the advances in information technology and communications TIC, platforms are required to enhance the harmonious development and innovation of the technological and academic sector, such as the storage of information; integrity, availability or recovery in case of disaster; standards that allow the integration and reuse of academic material; tools that allow the design and construction of an educational innovation model based on multiple representations and the digital ecosystem.

One of the technological advances to support education are remote and virtual laboratories [4]. That is how great benefits are obtained such as: availability, observability, accessibility, minimization of administration and travel and security costs [5]. This makes it a complex system and needs a design and configuration according to their needs.

A virtual laboratory can be defined as an electronic simulation space, which aims to approximate the environment of a traditional laboratory, for collaboration and remote experimentation in order to investigate or carry out other creative activities, develop and disseminate results through the use of TIC [6]. As for the recreation of reality, multiple representations that allow the understanding of a phenomenon in a 
Frey Alfonso Santamaría-Buitrago, Javier Antonio Ballesteros-Ricaurte, Ángela María GonzálezAmarillo

given context will be used. This implies the recognition of the context influence and the importance of the availability of digital tools that the individual has to build a representation [7].

Virtual laboratories have become an important tool in the academy as they are one of the most useful and safe ways to experiment, analyze and verify behaviors without the involvement of risks. In some cases, they also allow to show different real situations in a simple, intuitive and economical way, before being put into actual practice. However, when it comes to implementing and working with these types of laboratories, some inconveniences can occur, such as: architecture, installation and complex configurations, becoming a research topic.

Considering the importance of technology at the service of education, it is proposed to develop an ecosystem for academic, open, reusable and interoperable processes, through the use of the IMS Learning Tools Interoperability ${ }^{\circledR}($ LTI $\circledast)$ standard that is the core of the design of the framework for the implementation of the ecosystem through virtual laboratories.

In the same way, this ecosystem for virtual laboratories uses heterogeneous resources and simulators, in order to facilitate decision-making related to learning management, research and associated processes. The model created uses engineering design techniques [8], Systems for Learning Management (LMS Learning Management System) and Content Management System (LCMS Learning Content Management System).

This document contains the materials and methods that explain the generalities on which the development of the ecosystem is based; the learning ecosystem, the components and the relationships that exist are described; the next section explains the method of developing virtual laboratories; then, the prototype that is implemented; concluding in the last section with the results obtained.

\section{METHOdOLOGY}

For the design of the model, TICs are conceived as tools that allow the scheme and construction of a digital ecosystem as it is exposed by [9], who affirms that a digital ecosystem is constituted by digital means considered as entities with identity 
and own life that change depending on how they are consumed and distributed. The model will be designed using engineering design techniques.

Engineering design [10], applied to the development of artifacts, in this case digital ecosystems, acts as a response to various orientations that involve attention to an oriented process, with a defined strategy and with a specialized human resource. In this area, the design phase for the development of educational software must be carried out at three different levels: the educational, the communicational and the computational [11]. Therefore, it is considered that the design of a digital ecosystem should include the synthesis of its main characteristics, its description, its technical requirements and its didactic characteristics. On the other hand, this design must contemplate the definition of the instructional and pedagogical function, the navigation scheme that will allow visualizing the structure and general contents. Finally, the navigation controls that allow the user to interact with the machine will be defined and the forms of dialogues between the user and the application will be described [12].

\section{A. Learning Tools Interoperability (LTI)®}

It's a specification developed by the IMS Global Learning Consortium (IMS GLC), a standard aimed at integrating the launch of external content (tool provider) from the LMS learning management system (consumers).

When an event occurs, for example, access to a resource unlocks an exchange of variable messages that are passed from the LTI link, which include the following information:

- Name of the institution or LMS instance

- Username within the LMS instance

- Role or course within the LMS instance

All these variables are encapsulated in a secret authentication code shared between the LMS and the LTI service provider.

The basic objective behind the development of the LTI specification is to allow the smooth connection of externally hosted web-based applications, as well as content 
Frey Alfonso Santamaría-Buitrago, Javier Antonio Ballesteros-Ricaurte, Ángela María GonzálezAmarillo

or tools, from simple communication applications such as chat, to specific domain learning environments or complex topics [8].

As for the recreation of reality, multiple representations that allow the understanding of a phenomenon in a given context will be used, this implies the recognition of the influence of the context and the importance of the availability of digital or cultural tools with which account the individual to build a representation [13].

\section{B. Technological ecosystem for academic experimentation}

Before specifying the structure and scope of the technological ecosystem, it is necessary to contextualize the term within learning environments [14]; a technological system is a set of physical and logical components, as well as the set of relationships that they maintain with other subsystems such as: resources, exchange systems, conflicts, power mechanisms or the impacts that can be generated, highlighting that if the ecosystem is oriented to training management is called the learning ecosystem or e-learning ecosystem.

The ecosystem is where they will interfere in a learning process that is robust and has the following characteristics [11, 12]:

- Selection of the learning strategy to be used, taking into account the proposed needs and objectives.

- Selection of the appropriate LMS for the implementation of means, resources, technology for the development of synchronous and asynchronous activities.

- Pedagogical design to use that meets the needs of the proposed objective.

- Elements that integrate the ecosystem, maintaining a standard and allowing the interoperability of the ecosystem.

- Ease of interactions and relationships between them that allow adaptation to changes. 


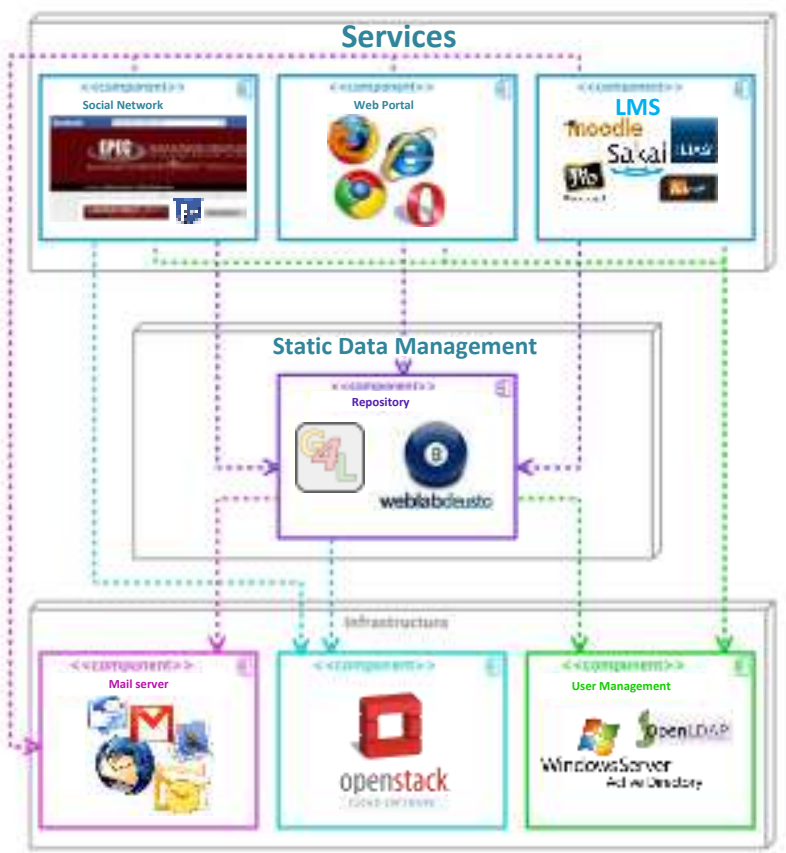

Fig. 1. Architectural pattern. Adapted from [7].

Therefore, it is concluded that we are in a world that is moving rapidly, where everything changes, where knowledge and the means to access it change very quickly. For that reason, the learning ecosystem must be a dynamic and constantly moving system, which allows to always be updated, since it becomes the frequent interaction not only of contents but also of learning experiences.

In [7], the authors provide the appropriate framework to define a series of common points and an Architectural Pattern, represented in Fig. 1, for the definition of elearning ecosystems based on Open Source developments that a technological ecosystem must have:

- Infrastructure: User management, data management and the implementation of Open Source software, mail server, among others.

- Static data management: There are the process and workflows necessary to manage the ecosystem, the components of the ecosystem that allow the reuse, flexibility and adaptability of the system against changes, the storage of information that permits the analysis for the decision making.

- Services: There is the selected LMS, the web portal, components that allow the integration of social tools, training strategies and plans. 
Frey Alfonso Santamaría-Buitrago, Javier Antonio Ballesteros-Ricaurte, Ángela María GonzálezAmarillo

\section{SYSTEMS COMPONENTS}

When planning and designing a learning ecosystem, it is essential to take into account the fundamental components that define its general structure [15]: actors, activities, pedagogical objectives / content, instructional content and technological infrastructure; serving the purpose of the project. The different elements, their characteristics and the resources that support the development of their functions within the ecosystem are listed below:

1) Users. Teachers and apprentices are the main actors of the system, who, together with TIC experts and pedagogy experts, make up what will be called: ecosystem users.

2) Administrative and learning activities. Such as user management, courses and groups, communication among the actors, the evaluation process, presentation of exams or job creation and delivery of tasks, distribution of materials, communication and interaction, management of the spaces of communication [16].

3) Pedagogical scenario. According to Bloom's taxonomy, experimentation environments must include a pedagogical scenario based on inquiry, which includes research activities and their sequence, a description of the activities that are carried out online and offline and a description of the workflow and expected results obtained individually, collaboratively and cooperatively. The phases of the pedagogical scenario are observed in Fig. 2 and are:

- Orientation, to capture the student's attention, (research question).

- Conceptualization of the theory and concepts of the research field.

- Research, experimentation in the laboratory, whether real, virtual or remote.

- Conclusion based on the investigation guided by the original question.

- Discussion (the student discusses with his classmates or the teacher relevant aspects of the learning activity). 


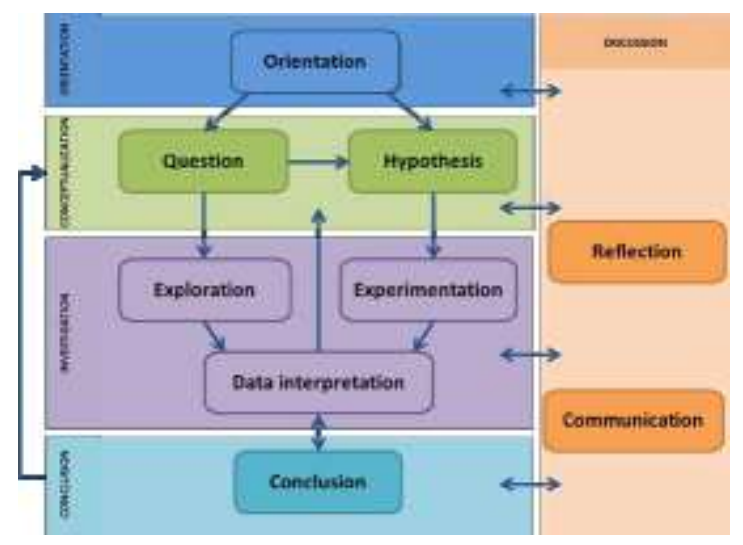

Fig. 2. Phases of the pedagogical scenario. Adapted from [7].

The proposed phases arise from the Go-Lab project of the European Union [17], a learning scenario based on international standards, that describes the offline activities of students and teachers and independent domain; the activities, materials and interactions of teachers and students.

4) Instructional model. The objective of an instructional model is to guide and describe the teaching-learning process; different educational contents and their respective learning and evaluation activities are planned, designed, developed and presented within a given context to achieve the pedagogical learning objectives [18]. There have been and evolved many models of instructional design based on the analysis and study of several authors of pedagogy and instruction, but technological advances bring with them the evolution in pedagogical aspects and the emergence of new models or specifications aimed at content interoperability educational $[19,20]$, the purpose of IMS Learning Design is precisely to facilitate the interoperability of instructional or educational designs. For the creation of courses, programs or material for online learning, there is a diversity of models of instructional design, some with behavioral theories, or cognitivist and others with a constructivist approach; however, the most relevant specification design requirements are as follows:

- Do not limit the contents of the courses, allow the learner's autonomy in order to determine the direction and the most subjective evaluation

- Activity planning that contributes to the development of the purposes and objectives of the learning units. 
Frey Alfonso Santamaría-Buitrago, Javier Antonio Ballesteros-Ricaurte, Ángela María GonzálezAmarillo

- Use the rules and standards that govern the implementation of online or virtual courses.

- Allow collaborative and cooperative work enabling them to act from different roles.

One of the advantages of the IMS-LD specifications is that it has made possible the development of compatible Execution Engines, such as CooperCore, SLeD Player and RELOAD Player, which enable their execution in some open source LMS [21].

Based on the characteristics of the technological ecosystems and the archetype or technological pattern and the elements that compose it, the ecosystem is required for the deployment and management of virtual laboratories, synthesized in Fig. 3.

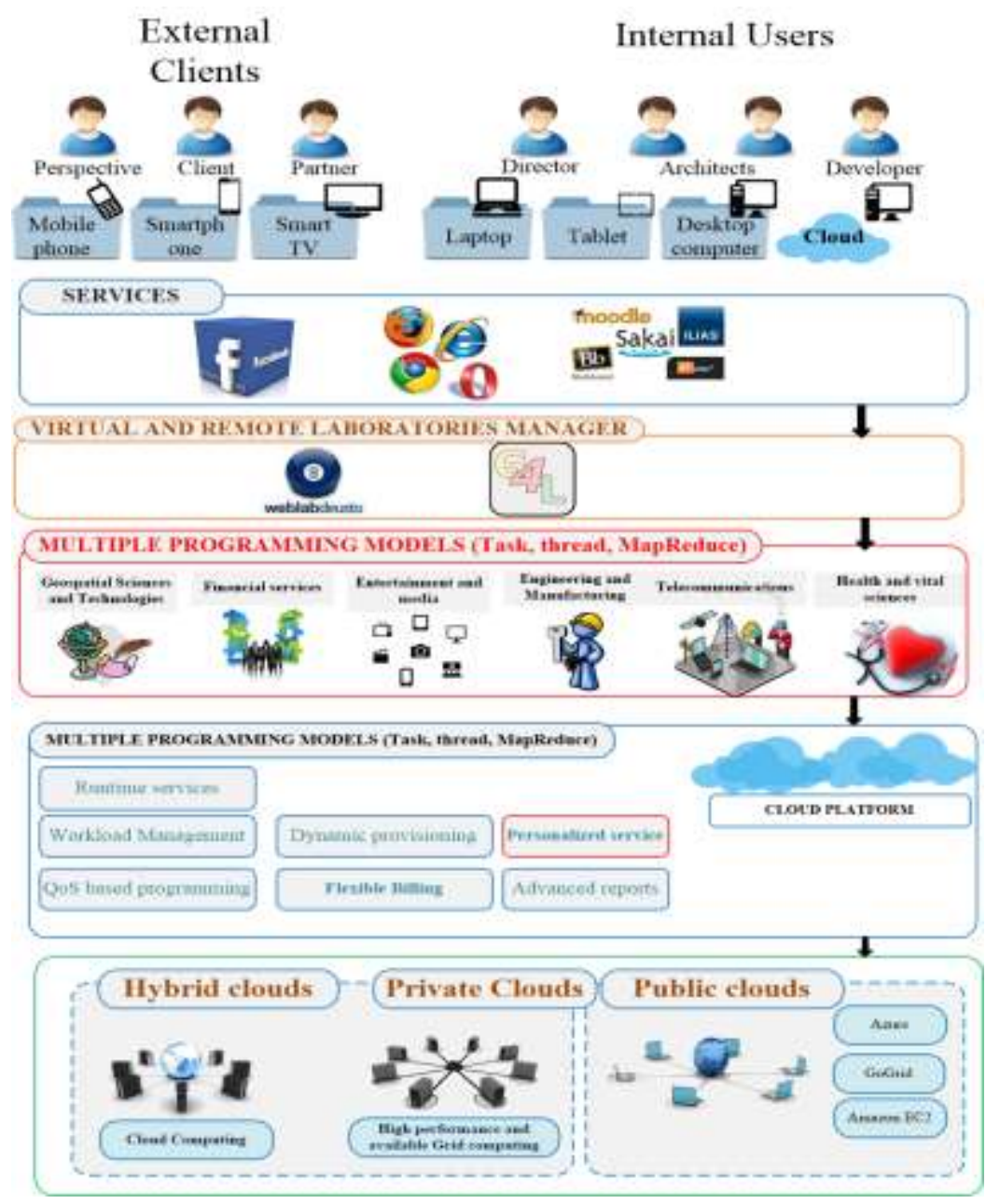

Fig. 3. Ecosystem overview. 
5) Technological platform. For the proposed ecosystem, it must support the use and control of scalable, replicable, interconnected, reliable, compatible, collaborative and manageable laboratories and virtual experiments for teaching and learning purposes, interactive online experiments for the control of real instruments or the use of simulated user interface solutions designed for the usability of experiments, for specific pedagogical contexts. Based on these characteristics, the following technological systems or platforms are chosen:

- Virtual laboratories

- Laboratory management systems and RLMS remote laboratory management system (for its acronym in English Remote Lab Management Systems)

- Learning management systems

- Mesh computing and cloud computing solutions

\section{Virtual Laboratories Development Method}

The laboratory development method is independent of the design methodology of the environment or learning scenario, given its complexity and length of the process [22]. The objective at the end of each phase, as seen in Table 1, is to have a palpable result and to document each of the phases [23].

Table 1. Laboratory development procedure.

\begin{tabular}{|l|l|}
\hline \multicolumn{1}{|c|}{ Phase } & \multicolumn{1}{c|}{ Task } \\
\hline 1. Organization and control & 1.1 Organization \\
& 1.2 Monitoring \\
\hline 2. System requirements & 2.1 Needs and requirements analysis \\
& 2.2 Preparation of the requirements document \\
\hline 3. Preliminary design & 3.1 Review of requirements \\
& 3.2 Preparation of preliminary design \\
\hline 4. Development & 4.1 Coding \\
& 4.2 Tests \\
& 4.3 User Documentation \\
& 4.4 Development documentation \\
\hline 5. Connectivity & 5.1 Connectivity tests \\
& 5.2 Connectivity Documentation \\
\hline 6. Testing, usability and integration & 6.1 Usability tests \\
& 6.2 Configuration and testing of new experiments \\
\hline
\end{tabular}


Frey Alfonso Santamaría-Buitrago, Javier Antonio Ballesteros-Ricaurte, Ángela María GonzálezAmarillo

The phases of the development method begin in the organization and control which allow preparing the planning and launch of the project (see Fig. 4), the procedure or method relates each phase and is a cyclical process to include new experiments or laboratories or perform the necessary adjustments such as technological update or experimentation.

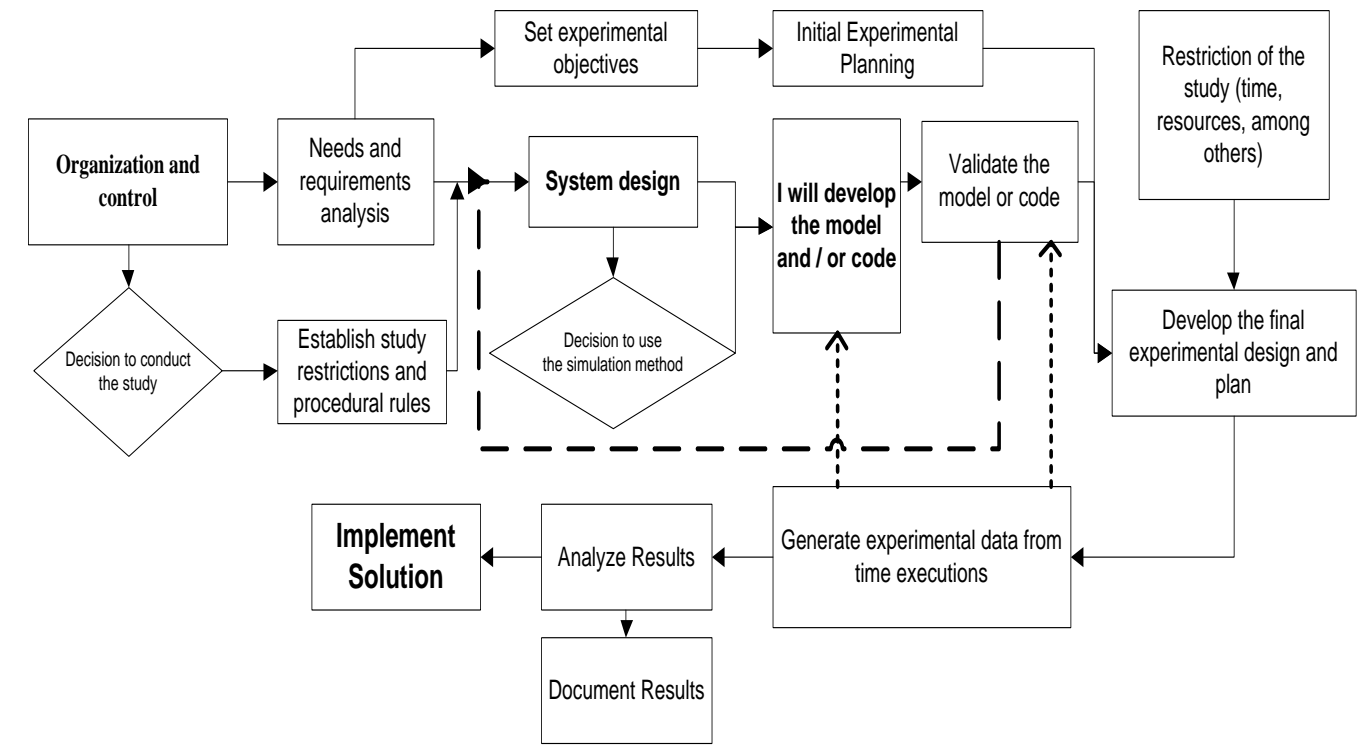

Fig. 4. Simulation process. Prepared by the authors based on the original image in [23].

\section{Virtual Laboratory Prototype}

Below is the prototype of a virtual laboratory aimed at the realization of teaching practices in programming subjects in $\mathrm{C} / \mathrm{C}++$ language, processing and Java, Matlab [24], as well as allowing experimentation in areas such as: embedded system design [25], microcontrollers [18] and 3D animation system [26]. The general scheme of the laboratory is presented in Fig. 5.

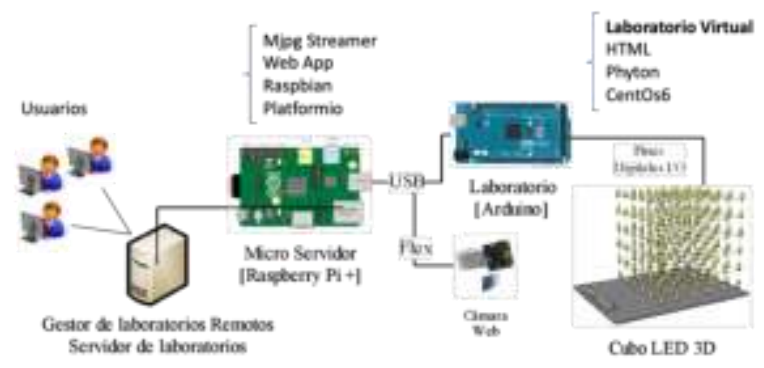

Fig. 5. Overview virtual laboratory architecture. 
The micro-server installed and configured on the Raspberry Pi reduced-plate computer, with Rasbpian operating system that contains the PlatformlO open source ecosystem or constructor, which has the function of compiling the code sent through the user interface and transferring it to the Arduino board, in addition to acting as a streaming or video broadcast server, to enable the user to observe what happens in the laboratory.

OpenStack is implemented, which has four environments: the first one is the virtual laboratory, which is HTML, Phyton and CentOs6; the second one, the WebLab Deusto experiment server. WebLab Deusto is an initiative of the University of Deusto which offers several laboratories for free over the Internet, the underlying software is available under an open source license [5]. It contains the plug-in Weblab Deusto, Deusto, Phyton (Virtual env), MySql, Debian; the third one, Labmanager, constituted by Phyton (Virtual env), MySql, Debian; and the fourth one, LMS Sakai, which consists of Sakai 10.2, Apache Tomcat, MySql Server, Debian.

Gateway4labs laboratory manager implementation: Gateway4labs is aimed at the integration of multiple laboratories in different learning environments such as: LMS, CMS content management systems or Personal Learning Environments (PLE) [27], for this it refers on a laboratory manager responsible for manage access from the LMS to the remote laboratory manager RLMS.

Finally, we have the client, which only needs any operating system with any web browser.

\section{A. Experiment implementation}

Due to the experiment code is compiled on an Arduino card, it is necessary to generate an Arduino sketch. The sketch must be stored in the main.ino file inside the src / directory located in the arduino / experiment server directory.

1) LMS (Learning Management System). To define the user interface and given the project environment, it is determined to choose a system for managing LMS learning, which allows management and interaction with the platform. This is based on the characterization, selection and choice of the computer system to use; this 
Frey Alfonso Santamaría-Buitrago, Javier Antonio Ballesteros-Ricaurte, Ángela María GonzálezAmarillo

tool should receive the user's requests, whether it is the administrator, teacher, student or guest, and the consumption of the services and learning tools necessary for each of the roles.

2) Deployment of the Cloud Computing platform. For the choice of the cloud platform, it was taken into account that its distribution and open source be free, [28-29], after the analysis it was determined to install OpenStack, the most relevant criteria and with "Very High" score were: easy adaptability to different hardware environments, offering the possibility of scalability in a simple way, which enables to create network topologies in different ways, web interface that provides the necessary functionality to control the cloud in a simple way, simple installation, instance management and support.

3) Integration and deployment of the proposed platform. This section shows the development in implementation of the ecosystem prototype and each of its components (see Fig. 5), from the virtual laboratory, the virtual laboratory manager WebLab Deusto, the LabManager laboratory manager of Gateway4Labs and the LMS Sakai that it will consume these resources through LTI tools, so that end users have access to the platform and its resources. This platform and its integrated tools will be virtualized and managed within a free software based cloud infrastructure (OpenStack).

4) Integration of virtual laboratories in the RLMS Weblab-Deusto. WebLab Deusto allows the management of users, the registration of laboratories and the definition of access permits for the use of laboratories. The first step to register the laboratory creates the category "Experiments" menu, set up the experiments and their categories. The categories were defined as follows: virtual laboratories and remote laboratories.

5) Lab Manager. The purpose of this tool is to administer laboratories already integrated into WebLab-Deusto and manage them in order to allow any LMS to use them.

Two important parts were executed in the first part, the RLMS that contains the laboratories was managed, in this case WebLab-Deusto, and in the second part 
the LMS was managed, that is, the Sakai which is the one that will interact directly with university users.

The laboratory manager administrator can manage the available laboratories, manage which LMS can access it, and assign the remote laboratories to each LMS. Created the project and the network, the next step is the creation of instances, prior to the creation of the image of the operating system necessary for the different applications offered in the cloud. Creating an instance is choosing the image to instantiate. The creation of the instance consists of:

- Choose the image to be instantiated. The Ubuntu server 15 image will be chosen for the project.

- Choose the configuration that the virtual machine will have, both hard disk and RAM and number of processors, OpenStack, has 3 pre-configured and modifiable types: Small, Medium y Large.

- Assign the Security group with which the instance will work. In the "Access and Security" item you can create security groups, each with specific iptables rules.

- Assign the RSA password: to assign the secure password, you must first create it. The public key is saved by the system and the private one is downloaded by the user to access the instance.

- Choose the internal network in which the instance will be connected.

- Assign a Floating IP.

Fig. 6 represents the changes in the current situation in access to learning managers and virtual and remote laboratories, compared to the proposed architecture. Thanks to the LMS authentication service and educational standards, which enable laboratories and LMS to communicate in a standard way using a common $\mathrm{API}$, users have a single point of access and content management, collaborative tools and communication among others, providing reusability and portability.

The potential can be summed up in a simple way: by properly configuring the proposed platform, a network, repository or bank of virtual laboratories can be automatically deployed and shared in federated environments with only a few steps and thus be able to have a scenario ready to put into operation different research 
Frey Alfonso Santamaría-Buitrago, Javier Antonio Ballesteros-Ricaurte, Ángela María GonzálezAmarillo

and testing environments, simulated in the laboratory with relatively few equipment emulating real environments.

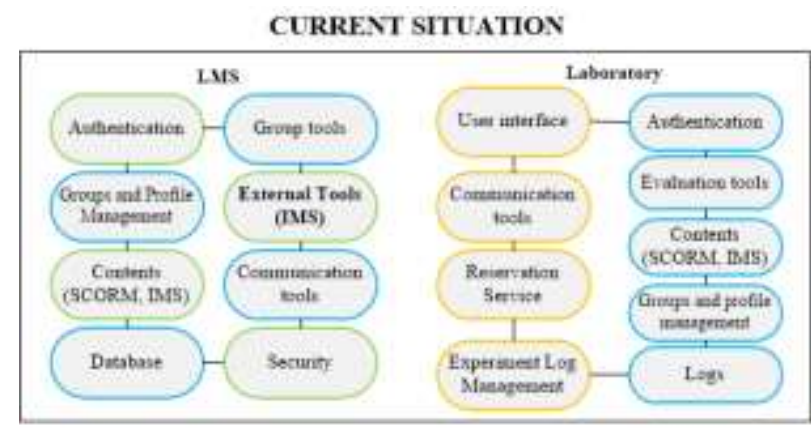

SITUATION AFTER APPLYING THE APPROVED ARCHTECTURE

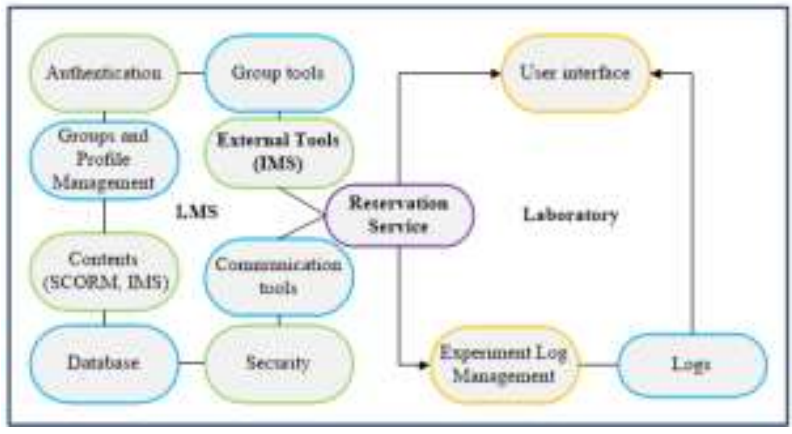

Fig. 6. Current situation versus proposed situation.

\section{CONCLUSIONS}

The proposed ecosystem brings significant advantages to TIC mediated learning environments, thanks to the synergy that is consolidated by integrating each of its components and the advantages that each brings, thus enhancing the integration of other actors such as learning networks, thematic research networks and laboratory networks, among others.

The ecosystem is strengthened by the advantages provided by cloud computing, such as the ease of deployment and provisioning of virtual laboratory experimentation resources, offering users direct interaction with laboratory equipment. It also has a high educational impact to solve problems related to the configuration of the experiments.

The installation on virtual machines offers less performance, and for robust or production research projects the ideal is to install it on physical machines, since the scripts that automate the installation and configuration, and even allowing facilities 
Ecosystem for the deployment and management of virtual laboratories based on the standard IMS LTI

to be modified for a real environment, have worse performance and are more demanding in terms of hardware requirements.

\section{AUTHORS CONTRIBUTION}

The coordination, structure and organization of the information in the document was carried out by Frey Alfonso Santamaría Buitrago. The collection and analysis of the information, as well as the writing of the document, were carried out by Javier Antonio Ballesteros-Ricaurte and Ángela María González Amarillo. Likewise, all authors made significant contributions to the document and agree with its publication and state that there are no conflicts of interest in this study.

\section{REFERENCES}

[1] M. Melendro, "The Ecosocial Perspective in the socioeducative intervention with excluded youth. A comparative study of Canada, Belgium and Spain," Revista Española de Educación Comparada, vol. 17, pp. 197-218, 2011.

[2] M. Subramaniam, B. lyer, and V. Venkatraman, "Competing in digital ecosystems," Business Horizons, vol. 62 (1), pp. 83-94, 2019. https://doi.org/10.1016/j.bushor.2018.08.013.

[3] Ministerio de Tecnologías de la Información y las Telecomunicaciones. El Plan Vive Digital Colombia 2014 -2018. Bogotá D.C.: MinTics, 2014.

[4] P. D. Godoy, R. Cayssials, and C. García, "A WSN Testbed for Teaching Purposes," IEEE Lat. Am. Trans., vol. 14 (7), pp. 3351-3357, 2016. https://doi.org/10.1109/tla.2016.7587641.

[5] T. J. Mateo, I. J. Fernández De Viana, J. Espejo, and A. García, "Using identity provider and automatic resource management to improve a remote networking lab," IEEE Lat. Am. Trans., vol. 16 (5), pp. 1547-1556, 2018. https://doi.org/10.1109/tla.2018.8408453.

[6] J. P. Vary, "Report of the Expert Meeting on Virtual Laboratories," in Ames, May. 1999.

[7] A. García-Holgado, and F. J. García-Peñalvo, "Patrón arquitectónico para la definición de ecosistemas de eLearning basados en desarrollos open source," in International Symposium on Computers Education (SIIE), Logroño, La Rioja, Spain, Nov. 2014. https://doi.org/10.1109/siie.2014.7017711.

[8] R. J. Carrión, M. Díaz, and D. López, Integración de juegos educativos en edX. Spain-Madrid: Universidad Complutense de Madrid, 2014.

[9] C. Islas, and M. del R. Carranza, "Ecosistemas digitales y su manifestación en el aprendizaje: análisis de la literatura," RED. Rev. Educ. a Distancia, vol. 55, pp. 1-13, Dec. 2017. https://doi.org/10.6018/red/55/9.

[10] M. Guerrero, B. Hernandis, and B. Agudo, "Estudio comparativo de las acciones a considerar en el proceso de diseño conceptual desde la ingeniería y el diseño de productos," Comp. study actions to consider Process Concept. Des. from Eng. Prod. Des., vol. 22 (3), pp. 398-411, Sep. 2014. https://doi.org/10.4067/s0718-33052014000300010.

[11] D. Dueñas, A. Gómez, R. Toscano, and M. Caro, "Sinopsis de metodologías y modelos de software

Revista Facultad de Ingeniería (Rev. Fac. Ing.) Vol. 28 (53), pp. 79-99. Octubre-Diciembre 2019.

Tunja-Boyacá, Colombia. L-ISSN: 0121-1129, e-ISSN: 2357-5328, DOI:

https://doi.org/10.19053/01211129.v28.n53.2019.10148 
Frey Alfonso Santamaría-Buitrago, Javier Antonio Ballesteros-Ricaurte, Ángela María GonzálezAmarillo

educativo," Acta Sci. Informaticae, vol. 1, pp. 70-74, 2017.

[12] G. Sánchez, M. Ángel, and T. Cosío, "Metodología para el desarrollo de software multimedia educativo MEDESME," CPU-e Rev. Investig. Educ., vol. 23, pp. 216-226, 2016. https://doi.org/10.25009/cpue.v0i23.2169.

[13] A. García. and F. Flores, La estructura de la materia en estudiantes de secundaria y bachillerato. Ciudad de México-México: Universidad Autónoma Metropolitana, 2005.

[14] A. García, and F. J. García, Análisis de integración de soluciones basadas en software como servicio para la implantación de ecosistemas tecnológicos corporativos. Spain-Salamanca: Universidad de Salamanca, 2004.

[15] T. Nallely, Ensayo sobre el diseño de ambientes de aprendizaje. México- Hidalgo: Universidad Autónoma del Estado de Hidalgo, 2009.

[16] R. Ferreiro, and A. De Napoli, "Más allá del salón de clases: Los nuevos ambientes de aprendizajes," Rev. Complut. Educ., vol. 19 (2), pp. 333-346, 2008.

[17] P. Orduña, Laboratorios remotos de mañana, hoy: el proyecto Go-LAB, 2015. [Online]. Available at: http://revistaingenieria.deusto.es/laboratorios-remotos-de-manana-hoy-el-proyecto-go-lab/.

[18] R. Álvarez, "El e-learning, una respuesta educativa a las demandas de las sociedades del Siglo XXI," Rev. Medios y Educ., vol. 35, pp. 87-96, 2009.

[19] J. Á. Martínez-Ucero, and P. Lara-Navarra, "Interoperabilidad de los contenidos en las plataformas de e-learning: normalización, bibliotecas digitales y gestión del conocimiento," RUSC. Universities and Knowledge Society Journal, vol. 3 (2), pp. 1-8, 2007.

[20] A. X. Reyes, L. F. Uribe, and S. Cataño, "Modelo para la interporalidad de contenidos educativos en diversas plataformas," Lámpsakos, vol. 11, pp. 50-58, 2014. https://doi.org/10.21501/21454086.1212.

[21] B. Fernández, J. L. Sierra, I. Martínez, and P. Moreno, Educación. Motores de ejecución compatibles con IMS-LD. [Online]. Available at: http://ares.cnice.mec.es/informes/20/contenidos/12.htm.

[22] L. Lloréns, Y. Espinosa, and L. C. Murillo, "Criterios de un modelo de diseño instruccional y competencia docente para la educación superior escolarizada a distancia apoyada en TICC," Revista Electrónica Sinéctica, vol. 41, pp. 1-21, Jul. 2013.

[23] L. R. Gil, "Diseño e implementación de la plataforma Boole-WebLab-Deusto para el prototipado rápido de sistemas digitales mediante el uso de laboratorios remotos y realidad aumentada," Grade Thesis, Universidad de Deusto, Bilbao, Spain, 2013.

[24] A. Gil, D. Valiente, O. Reinoso, L. Payá. "Creación de un laboratorio remoto para la docencia de lenguaje $\mathrm{C} / \mathrm{C}_{++}, "$ in Conferencia Internacional de Ingeniería Mecánica y Energía Conferencia Internacional de Ingeniería Mecánica y Energía, 2010.

[25] Electronics Hub, How to build an $8 \times 8 \times 8$ LED cube using Arduino, 2018. [Online]. Available at: https://www.electronicshub.org/8x8x8-led-cube/.

[26] J. Aguilar, "Sistema de animaciones 3D para controlar un cubo de LEDs RGB modular basado en programación libre," Master Thesis, Universidad Politécnica de Barcelona, Barcelona, Spain, 2014.

[27] F. A. Santamaría-Buitrago, J. A. Ballesteros-Ricaurte, and J. S. González-Sanabria, "Plataforma cloud computing como infraestructura tecnológica para laboratorios virtuales, remotos y adaptativos -Cloud computing as technologic infrastructure for virtual, remote and adaptive labs," Rev. Científica, vol. 3 (23), p. 98, 2016. https://doi.org/10.14483/udistrital.jour.rc.2015.23.a8.

[28] B. Galarza, G. Zaccardi, D. Encinas, and M. Morales. "Análisis de despliegue de una laaS utilizando

Revista Facultad de Ingeniería (Rev. Fac. Ing.) Vol. 28 (53), pp. 79-99. Octubre-Diciembre 2019.

Tunja-Boyacá, Colombia. L-ISSN: 0121-1129, e-ISSN: 2357-5328, DOI:

https://doi.org/10.19053/01211129.v28.n53.2019.10148 
Ecosystem for the deployment and management of virtual laboratories based on the standard IMS LTI

Openstac," in XXI Congreso Argentino de Ciencias de la Computación, Junín, Argentina, 2015.

[29] A. C. Osuna, "Creación de sistema Cloud con OpenStack," Grade Thesis, Universidad Politécnica de Valencia, Valencia, Spain, 2016.

Revista Facultad de Ingeniería (Rev. Fac. Ing.) Vol. 28 (53), pp. 79-99. Octubre-Diciembre 2019.

Tunja-Boyacá, Colombia. L-ISSN: 0121-1129, e-ISSN: 2357-5328, DOI: https://doi.org/10.19053/01211129.v28.n53.2019.10148 